\title{
Genetic Analysis of the Populations of Japanese Anchovy (Engraulidae: Engraulis japonicus) Using Microsatellite DNA
}

\author{
Hon-Tsen Yu, Yann-Jium Lee, Shiao-Wei Huang, and Tai-Sheng Chiu*
}

Department of Zoology, National Taiwan University, Taipei, Taiwan, ROC 106

\begin{abstract}
We analyzed the population structure of the Japanese anchovy (Engraulis japonicus), a small pelagic fish, using 6 microsatellite DNA loci. The anchovy is known to have 2 separate spawning populations, one near northeastern Taiwan in the Pacific Ocean and the other near southwestern Taiwan in the Taiwan Strait. The planktonic larvae then drifted north to the feeding grounds in the East China Sea to advance in their life history. Three populations of the anchovy were analyzed, including 2 temporal population from the northeastern spawning ground (I-Lan 1999 and I-Lan 2000) and one population from the southwestern spawning ground (Peng-Hu 2000). The genetic variability of the 6 loci was high for all the populations. The average numbers of alleles per population ranged from 25.5 to 32.3 , and the average observed heterozygosity ranged from 0.559 to 0.650 . A significant population differentiation was found between geographic populations but not between the temporal populations. However, the level of geographic differentiation was weak, average $F_{S T}$ 0.0088. The significant geographic population structure indicated that the populations of 2 spawning grounds belonged to separate stocks. Moreover, 16 of the 18 population-locus cases showed significant departure from Hardy-Weinberg equilibrium, implying that each spawning population in turn consisted of mixed native stocks. Finally, we posed 3 population models to be evaluated against the genetic data disclosed with the microsatellite markers.
\end{abstract}

Key words: stock, Engraulis, microsatellite, fisheries management.

\section{INTRODUCTION}

Japanese anchovies (Engraulis japonicus) comprise the major catch for anchovy larvae, which has been a traditional fishing practice in Taiwan (Chiu et al., 1997; Young and Chiu, 1994). The larvae are sold at good prices in local markets, since their nutritive value is highly prized. The economic significance of anchovy larvae has propelled the government to embark on population studies on the spe-

Received October 2, 2001; accepted January 10, 2002.

*Corresponding author: telephone 886-2-23630231, ext. 2128; fax 886-2-23636837; e-mail:tschiu@ccms.ntu.edu.tw cies and to take measures to reduce exploitation of the larvae. Consequently, a seasonal closure to the anchovy harvest was announced in 1999.

Chiu et al. (1997) analyzed monthly geographic distribution of the larval stocks and established that the adult anchovies migrate from the East China Sea to spawn in coastal waters of Taiwan. The planktonic larvae then drift back to the East China Sea to complete their life cycle. So far, at least 2 spawning grounds of the Japanese anchovy have been identified near Taiwan, one in the northeastern coast of Taiwan (in the Pacific Ocean) and the other in the southwestern coast of Taiwan (in the 


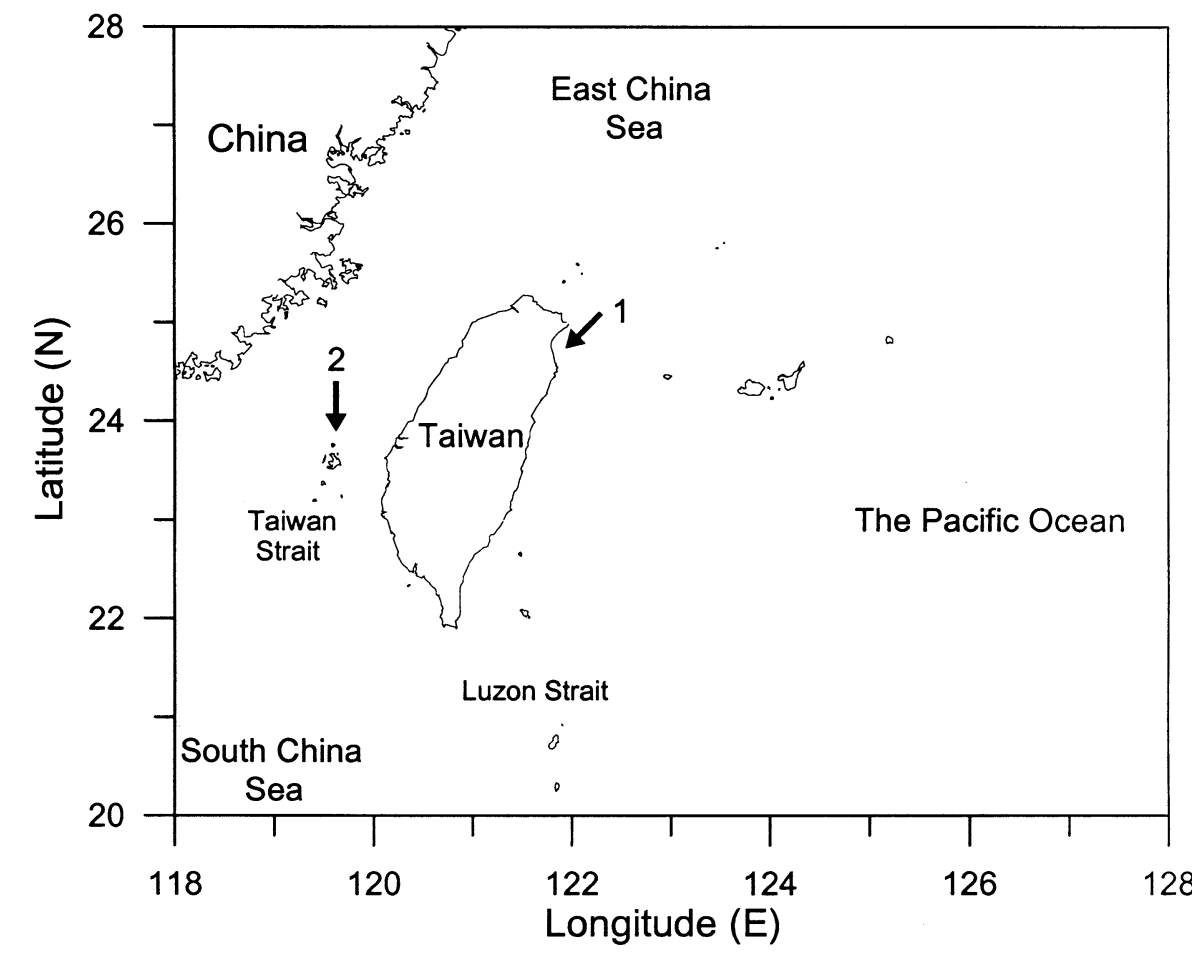

Figure 1. A map showing the 2 spawning populations and therefore sampling locations of Engraulis japonica in waters near Taiwan: 1, I-Lan; 2, Peng-Hu.
Taiwan Strait). In addition to its economic value, the Japanese anchovy is a key link in the marine food chain since its larvae feed on copepods (Shen, 1969; Hirakawa et al., 1997). Likewise, a similar diet was found in the European anchovy (Engraulis encrasicolus) (Plounevez and Champalbert, 1999).

Microsatellite DNA loci are neutral genetic markers with high levels of polymorphism and are abundant in fish genomes (Wright and Bentzen, 1994; O’Reilly and Wright, 1995). The nature of the microsatellite markers has made them particularly amenable for genetic analyses of natural populations (Jarne and Lagoda, 1996). Knowledge of the genetic structure of fish populations is essential to effective management of the species of economic value. Applications of microsatellites in fishery science are increasing e.g., in salmonids (Beacham et al., 2000; Olsen et al., 2000), rockfish (Sekino et al., 2001), redfish (Roques et al., 1999), and eel (Wirth and Bernatchez, 2001).

We have attempted to clone microsatellite loci from the Japanese anchovy (Chiu et al., 2002). In this study, we applied these microsatellite markers to investigate the levels of polymorphism and to assess the temporal and geographic population differentiation in the species. The results of the genetic analysis were then evaluated against 3 hypothetical models of population structure of the adult anchovies in their feeding grounds. Such analyses will offer insights to fine-tune conservation and fishery management measures in the future.

\section{Materials And Methods}

\section{Sample Collection}

We sampled fish from 2 spawning grounds near Taiwanese waters (Figure 1). Adult Japanese anchovies were collected from local fishermen in I-Lan (representing the northeastern population). The fish were first placed on ice and frozen immediately after being transported back to the lab. The Peng-Hu samples (representing the southwestern population) were purchased from a local fish market and frozen right away. All the adults sampled weighed approximately $20 \mathrm{~g}$ and were 1-year-old, reaching sexual maturity. DNA samples were extracted from individual fish using a small piece $(20 \mathrm{mg}$ ) of tissue (muscle or liver). The tissue was ground, digested with proteinase $K$, and subjected to a standard phenol-chloroform procedure (Sambrook et al., 1989). The extracted DNA samples were stored at $-20^{\circ} \mathrm{C}$ until further treatments.

Initially, we sampled fish from I-Lan in 1999 for the purpose of cloning microsatellite loci and testing the applicability of the cloned markers. In 2000, efforts were made to include both I-Lan and Peng-Hu samples to ad- 
dress the issue of geographic population structure. The sampling in I-Lan for 2 consecutive years also allowed us to assess the temporal stability of the genetic population structure. A lack of stability might confound the geographic analysis.

\section{Microsatellite Loci}

Six polymorphic loci $\left(H_{e}>0.75\right)$ were selected to genotype the fish. Cloning and characterization of these loci were described by Chiu et al. (2002), where primer sequences and the optimal annealing temperatures for each locus are given. The sequences of the 6 loci were deposited in GenBank (accession numbers AF344655-AF344660). The loci and their repeat motifs are as follows: EJ2 $(\mathrm{CT})_{43}$, EJ9 $(\mathrm{TC})_{39}$, EJ27.1 (GA) 36, EJ27.2 (GAGAA) ${ }_{15}$, EJ35 (TG) ${ }_{15}$, and EJ41.1 (CACAA) 8 .

\section{Genotyping of the Fish}

Individual genotypes were determined by polymerase chain reaction (PCR) with radioactive primers. Each PCR reaction totaled $10 \mu \mathrm{l}$, containing $100 \mathrm{ng}$ of template DNA, 10 $\mathrm{mM}$ Tris- $\mathrm{HCl}, 50 \mathrm{mM} \mathrm{KCl}$, and $0.1 \%$ Triton X-100, 0.25

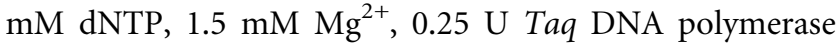
(Promega madison, Wis.), and $0.3 \mu \mathrm{M}$ of each primer, one of which was end-labeled with $\left[\gamma-{ }^{33} \mathrm{P}\right]$ ATP.

Amplification was carried out by the thermal profile: $94^{\circ} \mathrm{C} 5$ minutes, followed by 25 cycles of $94^{\circ} \mathrm{C} 30$ seconds, optimal annealing temperature 1 minute, $72^{\circ} \mathrm{C} 1$ minute, and final extension step at $72^{\circ} \mathrm{C}$ for 10 minutes. PCR products were run on regular denaturing $6 \%$ polyacrylamide sequencing gel. Sequence of pUC18 was used as a size marker to determine the allele sizes. The allelic PCR products differed in multiples of their repeat motifs. Genotypes were scored by 2 individuals independently, and only consistent results were included for analyses.

\section{Data Analysis}

Both observed heterozygosity $\left(H_{o}\right)$ and unbiased expected heterozygosity $\left(H_{e}\right.$; Nei, 1978) were calculated to estimate the genetic variability for the Japanese anchovy populations. Hardy-Weinberg expectation for each locus was tested by the Markov-chain method in GENEPOP Version 3.1 (Raymond and Rousset, 1995; available at http:// wbiomed.curtin.edu.au/genepop), which implements Fish- er's exact tests for multiple alleles (Guo and Thompson, 1992).

Population differentiation by 2 geographic locations and 2 temporal points was examined by determining $F_{\mathrm{ST}}(\theta)$ values (Weir and Cockerham, 1984) for 3 pairs of populations. The calculations were implemented in GENEPOP Version 3.1. Significant departures from 0 of the $F_{\mathrm{ST}}$ values were tested using permutations (see Dallas et al., 1995) and implemented in FSTAT (Goudet, 1995). In addition, we also calculated Slatkin's (1995) $R_{\mathrm{ST}}$, which is similar to Wright's $F_{\mathrm{ST}}$ except that its calculation is based on variance of allele size.

The variation component of genetic variation based on genotypic data was estimated by the analysis of molecular variation approach (AMOVA, Excoffier et al., 1992). The calculation was implemented in ARLEQUIN (Schneider et al., 2000; available at http://anthro.unige.ch/arlequin).

We employed a multivariate analysis based on the genotypes disclosed at the 6 microsatellite loci to visually examine the relationship among individual fish. Relatedness between any 2 individuals was measured by the coefficient of Sorensen based on the shared alleles at the 6 loci (Krebs, 1989), and a nonmetric multidimensional scaling (NMS) analysis was used to illustrate the relationship on a 2-dimensional plain (Pielou, 1984). Calculation of coefficient and the NMS were implemented in PC-ORD (McCunne and Mefford, 1999).

\section{Results}

\section{PCR Amplification and Genetic Variability}

The efficiency of the PCR amplification varied among loci. The PCR success ranged from 48 to 65 fishes for I-Lan 1999 $(N=74)$, from 47 to 70 fishes for I-Lan $2000(N=72)$, and from 42 to 55 fishes for Peng-Hu $(N=56)$, (Table 1). The average success rate by locus was best for EJ41.1 (92\%) followed by EJ35 (88\%) EJ27.2 (82\%), EJ2 (80\%), EJ27.1 $(75 \%)$, and EJ9 $(68 \%)$. The variation of success rate was in part contingent upon the quality of specimen preservation and DNA extraction.

The genetic variability was high at the 6 microsatellite loci and for the 3 populations of Engraulis japonica (Table $1)$. The average numbers of alleles per locus were in the following order: I-Lan 2000 (32.3), I-Lan 1999 (29.7), and Peng-Hu 2000 (25.5). The $H_{e}$ for the 3 populations was high and comparable, ranging from 0.911 to 0.918 . The $H_{o}$ 
Table 1. Statistics of Genetic Variability at Six Microsatellite Loci for the Three Engraulis japonicus Populations

\begin{tabular}{llll}
\hline & Population $^{*}$ & & \\
\cline { 2 - 4 } Locus and variable & I-Lan 1999 & I-Lan 2000 & Peng-Hu 2000
\end{tabular}

\section{EJ2}

$$
\mathrm{N}
$$

A (size range)

$\mathrm{H}_{\mathrm{o}}$

$\mathrm{H}_{\mathrm{e}}$

$P$

EJ9

$\mathrm{N}$

A (size range)

$\mathrm{H}_{\mathrm{o}}$

$\mathrm{H}_{\mathrm{e}}$

$P$

EJ27.1

$\mathrm{N}$

A (size range)

$\mathrm{H}_{\mathrm{o}}$

$\mathrm{H}_{\mathrm{e}}$

$P$

EJ27.2

$\mathrm{N}$

A (size range)

$\mathrm{H}_{\mathrm{o}}$

$\mathrm{H}_{\mathrm{e}}$

$P$

EJ35

$\mathrm{N}$

A (size range)

$\mathrm{H}_{\mathrm{o}}$

$\mathrm{H}_{\mathrm{e}}$

$$
P
$$

EJ41.1

$\mathrm{N}$

A (size range)

$\mathrm{H}_{\mathrm{o}}$

$\mathrm{H}_{\mathrm{e}}$

$P$

Average

$\mathrm{H}_{\mathrm{o}}$

$\mathrm{H}_{\mathrm{e}}$

A

o

60

36 (149-277)

$$
0.317
$$

0.963

$0.008^{* *}$

$$
48
$$

57

45

38 (149-273) 31 (149-279)

0.596

0.422

0.955

0.971

$0.000^{* * *}$

$0.000^{* * *}$

$47 \quad 42$

$32(224-320) \quad 36(222-308) \quad 27(220-300)$

$\begin{array}{lll}0.500 & 0.681 & 0.452\end{array}$

$\begin{array}{lll}0.947 & 0.968 & 0.954\end{array}$

$0.000^{* * *} \quad 0.023^{*} \quad 0.000^{* * *}$

$58 \quad 51 \quad 42$

33 (156-246) 44 (150-268) 34 (150-258)

$\begin{array}{lll}0.466 & 0.549 & 0.500\end{array}$

$\begin{array}{lll}0.968 & 0.978 & 0.973\end{array}$

$0.000^{* * *} \quad 0.000^{* * *} \quad 0.018^{* * *}$

$57 \quad 58 \quad 46$

30 (154-262) 29 (154-267) $23(157-259)$

$\begin{array}{lll}0.553 & 0.569 & 0.587\end{array}$

$\begin{array}{lll}0.958 & 0.953 & 0.941\end{array}$

$0.000^{* * *} \quad 0.000^{* * *} \quad 0000^{* * *}$

$65 \quad 60 \quad 52$

$28(178-270) \quad 26(182-241) \quad 25(177-220)$

$\begin{array}{lll}0.708 & 0.717 & 0.827\end{array}$

$\begin{array}{lll}0.925 & 0.921 & 0.927\end{array}$

$0.000^{* * *} \quad 0.000^{* * *} \quad 0.030^{* * *}$

$60 \quad 70 \quad 55$

$20(149-192) \quad 25(146-190) \quad 16(144-184)$

$\begin{array}{lll}0.783 & 0.757 & 0.673\end{array}$

$\begin{array}{lll}0.755 & 0.745 & 0.755\end{array}$

$0.312 \mathrm{~ns} \quad 0.474 \mathrm{~ns} \quad 0.031^{*}$

29.7

32.3

25.5

0.559

0.650

0.589

0.918

0.914 was highest in I-Lan 2000 (0.650), followed by Peng-Hu 2000 (0.589) and I-Lan 1999 (0.559).

The observed genotype frequencies were tested for agreement with Hardy-Weinberg equilibrium (Table 1). Among the 18 population-locus cases ( 3 populations $\times 6$ loci), only 2 cases (I-Lan 1999 and I-Lan 2000 at the locus EJ41.1) were at the equilibrium $(P>0.05)$, and the rest violated the Hardy-Weinberg equilibrium $(P<0.05)$, resulting in heterozygote deficiencies.

When the samples of 2 geographic populations of the same year (I-Lan 2000 and Peng-Hu 2000) were combined, all the cases at the 6 loci deviated significantly from HardyWeinberg equilibrium $(P<0.05)$. The same result was observed for the combined samples of I-Lan 1999 and Peng-Hu 2000. The deviation of the pooled samples (i.e., Wahlund's effect) was taken to illustrate that the 2 geographic populations could not be considered as one population; in other words, that 2 breeding populations existed.

\section{Genetic Variation at Population Level}

The variation at each locus (Table 2) was analyzed for temporal populations (I-Lan 1999 vs I-Lan 2000) and for geographic populations (I-Lan 2000 vs Peng-Hu 2000). For both temporal and geographic populations, the variation was mostly within individual populations $(>98 \%)$ rather than between populations $(<2 \%)$.

The levels of population differentiation were estimated by $F_{\mathrm{ST}}(\theta)$ and $R_{\mathrm{ST}}$ (Table 3 ). Both estimates showed a trend of minimal differentiation, yet $\theta$ values were greater between geographic populations than between temporal populations: 0.0099 between Peng-Hu 2000 and I-Lan 2000, 0.0076 between Peng-Hu 2000 and I-Lan 1999, and 0.0022 between I-Lan 1999 and I-Lan 2000, respectively.

The NMS analysis visually depicts the individual fish by their genotype combinations at 6 microsatellite loci (Figure 2). The analysis included 82 individual fishes of complete genotype sets based on the 6 loci. The results of NMS indicate that the individual genotypes of the 3 different populations overlapped substantially.

\section{Discussion}

The genetic diversity revealed at the 6 loci for E. japonica is high (Table 1), either for numbers of alleles or for the heterozygosity $\left(H_{o}\right.$ and $\left.H_{e}\right)$. The high average number of
${ }^{\dagger} N$, sample size; $A$, (size range), number of alleles and (numbers of the base pairs of PCR products); $H_{\mathrm{o}}$, observed heterozygoity; $H_{\mathrm{e}}$, expected heterozygosity; $P$, the exact $P$ value estimated by a Fisher's exact test of the observed genotypes to Hardy-Weinberg expectations.

${ }^{\star}$ Significant departure from expectations is determined by ${ }^{*} P<0.05$, ${ }^{* *} P$ $<0.01,{ }^{* * *} P<0.001$, ns $P>0.05$. 
Table 2. Variation Component of Genetic Variability at Six Microsatellite Loci for Engraulis japonicus

\begin{tabular}{|c|c|c|c|c|c|}
\hline \multirow[b]{3}{*}{ Locus } & \multicolumn{5}{|c|}{ Variation component (\%) } \\
\hline & \multicolumn{2}{|c|}{ I-Lan 1999 vs I-Lan 2000} & \multicolumn{3}{|c|}{ I-Lan 2000 vs Peng-Hu 2000} \\
\hline & Within & Between & Within & Between & \\
\hline EJ2 & 99.4 & 0.6 & 99.2 & & 0.8 \\
\hline EJ9 & 99.7 & 0.3 & 98.9 & & 1.1 \\
\hline EJ27.1 & 99.6 & 0.4 & 99.9 & & 0.1 \\
\hline EJ27.2 & 98.9 & 1.1 & 96.2 & & 3.8 \\
\hline EJ35 & 99.8 & 0.2 & 98.4 & & 1.6 \\
\hline EJ41.1 & 99.2 & 0.8 & 99.7 & & 0.3 \\
\hline
\end{tabular}

${ }^{\star}$ Components are analyzed for temporal populations (I-Lan 1999 vs I-Lan 2000) and for geographic populations (I-Lan 2000 vs Peng-Hu 2000).

Table 3. Estimated Level of Differentiation Between Population pairs $^{*}$

\begin{tabular}{lllr}
\hline & I-Lan 1999 & I-Lan 2000 & Peng-Hu 2000 \\
\hline I-Lan 1999 & - & 0.0022 & 0.0076 \\
I-Lan 2000 & 0.002 & - & 0.0099 \\
Peng-Hu 2000 & 0.002 & 0.007 & -
\end{tabular}

${ }^{\star} F_{\mathrm{ST}}(\theta)$ (Weir and Cockerham, 1984) values are above the diagonal, and $R_{\mathrm{ST}}$ (Slatkin, 1995) values are below the diagonal.

alleles per locus, ranging from 25.5 to 32.3 for the 3 populations, is noteworthy. The numbers of alleles were even greater when the 3 populations were considered together. The numbers of alleles per locus are as follows: 35 (EJ41.1), 37 (EJ35), 40 (EJ27.2), 45 (EJ9), 49 (EJ27.1), and 53 (EJ2) (Chiu et al., 2002). One reason we encountered a high number of alleles per locus was that a stringent measure was taken to screen for polymorphic loci. We used only 12 individuals in the initial screening and only those loci showing more than 1 allele were kept for future screening. The low sample number tested (12) ensured that we detected loci that are considerably polymorphic. Consequently, the numbers of repeat motifs, (36-43) were high for the dinucleotide loci that possessed more than 40 alleles: EJ2 (CT) ${ }_{43}$, EJ27.1 (GA) ${ }_{36}$, and EJ9 (TC) ${ }_{39}$. Similarly, the relation between the number of core repeat units and the level of allele variation was shown in human dinucleotide (CA) $)_{n}$ loci (Weber, 1990).

A second reason for the high allele number per locus is probably related to the large effective population size of the Japanese anchovy. Intuitively, the annual catch tonnage

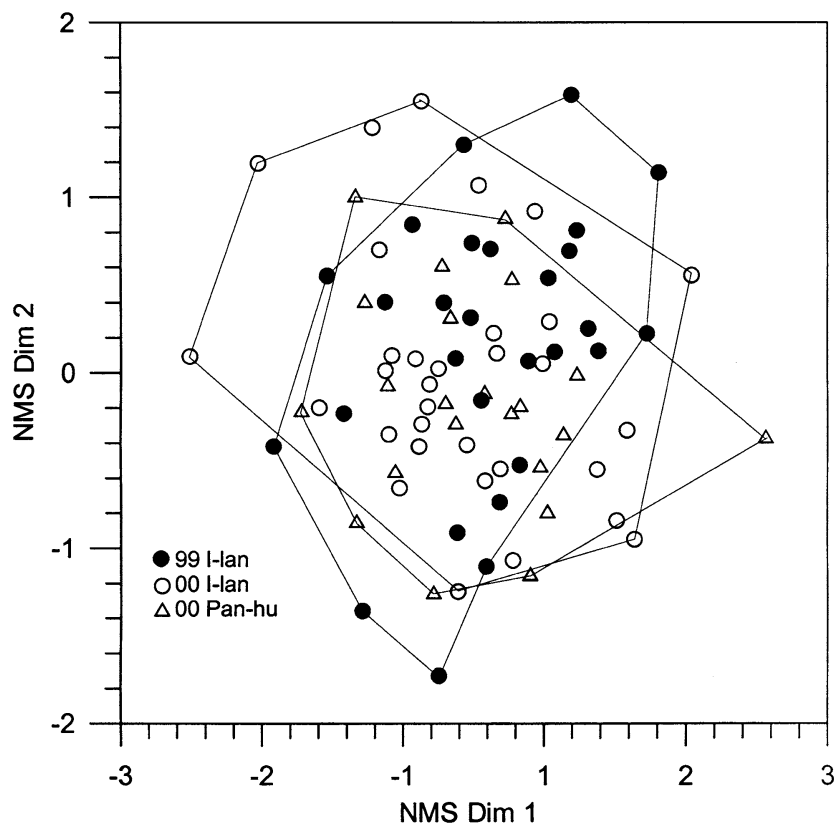

Figure 2. The nonmetric multidimensional scaling (NMS) analysis of genotypes of Engraulis japonicus based on 82 individuals with complete data at 6 loci. Black circles, I-Lan 1999; white circles, I-Lan 2000; white triangles, Peng-Hu 2000.

attests to the large census population (Chiu et al., 1997). Moreover, the effective population size $\left(N_{e}\right)$ can be estimated by calculating the $N_{e}$ (in a close random mating population) needed to maintain a given level of heterozygosity assuming, under mutation-drift equilibrium: (1) for infinite-allele mutation model $H=4 N_{e} \mu /\left(1+4 N_{e} \mu\right)$ (Kimura and Crow, 1964); and (2) for stepwise mutation model $H=1-1 /\left(1+8 N_{e} \mu\right)^{1 / 2}$ (Ohta and Kimura, 1973). $H$ equals expected heterozygosity $\left(H_{e}\right)$ and $\mu$ equals mutation rate. Here we take a general mutation rate of microsatellites 


\section{Hon-Tsen Yu et al.}

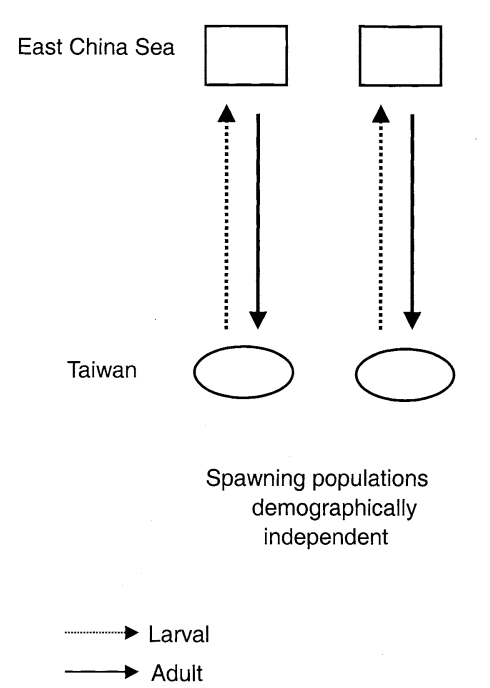

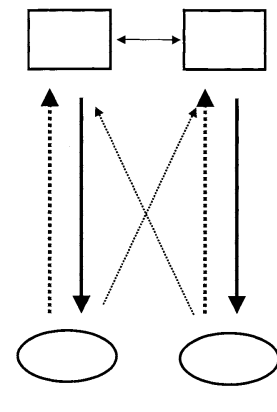

Spawning populations demographically independent with gene flow

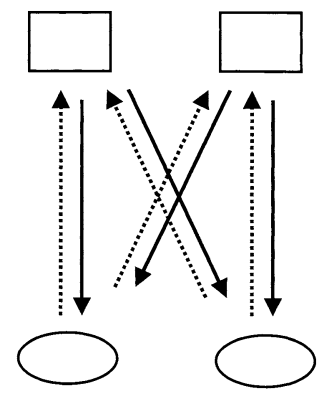

Panmictic population structure
Figure 3. Three population models of Engraulis ponica. Squares represent hypothetical adult populations in natural feeding grounds in the East China Sea. Ovals indicate two spawning populations in Taiwanese waters. The thickness of the arrows implies the intensity of migration. at $10^{-4}$ (Jarne and Lagoda, 1996). The estimated $N_{e}$ average across loci for the infinite-allele model and for the stepwise mutation model was $5.3 \times 10^{4}$ and $7.4 \times 10^{5}$, respectively. The large $N_{e}$ has ensured a large allele variance and thereby high allele numbers per locus, because, assuming neutral, the expected variance in repeat number $(V)$ depends on the effective population size and the mutation rate of the microsatellite locus, i.e., $V=2 N_{e} \mu$ (Moran, 1975). Nonetheless, a higher than usual mutation rate in the Japanese anchovy could still be a cause of the large allele numbers.

The majority (16 of 18) of the population-locus cases deviated from the Hardy-Weinberg expectation, showing heterozygote deficiency (Table 1). While the occurrence of null alleles (Pemberton et al., 1995) could not be ruled out, the consistent outcomes over multiple loci are likely to be attributed to Wahlund's effect (Hartl and Clark, 1989) or mixing of more than 2 independent random mating populations. Currently, no existing ecologic data that we are aware of can shed light on the population structure of the Japanese anchovy in the natural feeding grounds in the East China Sea.

Likewise, the departure from Hardy-Weinberg equilibrium of the combined samples of I-Lan and Peng-Hu indicated a mixing of populations by this artificial treatment. Therefore, the results implied that the 2 geographic spawning populations could be 2 separate populations, each of which, in turn, consists of multiple native stocks.

At the population level, we analyzed the genetic differentiation by 2 dimensions, geographic and temporal populations. The geographic differentiation was greater than the temporal differentiation. $F_{\mathrm{ST}}(\theta)$ values for geographic comparison were 3 to 4 times those of temporal comparisons (Table 3 ) and significantly different from 0 $(P<0.005)$. The significant geographic population structure implies that the east (I-Lan) and west (Peng-Hu) spawning populations should belong to 2 separate stocks. This conclusion is reinforced by the significant departure from Hardy-Weinberg equilibrium for the combined samples of the 2 spawning populations. Yet the genetic variation was largely contained within populations (Table 2 ), and there was substantial overlapping in genotypes of the 2 stocks (Figure 2).

Here we posed 3 models for the adult population structure of the Japanese anchovy (Figure 3) based on the fact that there are 2 separate spawning populations in Taiwanese waters. The first model and the last model represent 2 extreme cases of population structure: the first assumes the spawning populations are demographically independent, and the last assumes a panmictic structure (i.e., a complete mixing of the 2 spawning populations, either through larval migration or adult migration). The second, however, represents a compromise: the spawning populations are basically 2 demographically independent entities but are "connected" through gene flow. The 3 models can be evaluated with current genetic data.

Our genetic analyses of the Japanese anchovy appear to support the second model. First, the significant geographic population structure between the 2 spawning populations refutes the panmictic model. Second, the demographically independent model is also refuted because, despite a significant population structure, the differentiation is weak, $F_{\mathrm{ST}}(\theta)$ in the range of 0.0076 and 0.0099 . The low $F_{\mathrm{ST}}$ is typical of marine fishes (Ward et al., 1994) and indicates recurrent gene flow between the 2 spawning populations. 
The gene flow could result from the planktonic nature of the anchovy larvae (Young and Chiu, 1994; Chiu et al., 1997; Nakata et al., 2000). However, the migration of adults in the feeding grounds could also contribute to the gene exchange (Figure 3). At this point, neither ecologic nor genetic data are available to evaluate the demographic attributes of the gene flow.

The population genetic structure of Engraulis, as revealed by protein electrophoresis, is typical of marine fish in that it is low in genetic differentiation among subpopulations $\left(F_{\mathrm{ST}}\right.$ or $G_{\mathrm{ST}}$ in parentheses): E. capensis (0.005) (Grant, 1985); E. mordax (0.032) (Hedgecock et al., 1989); E. encrasicolus (0.003-0.026) (Bembo et al., 1996b; Tudela et al., 1999).

Engraulis encrasicolus has been a focal species for analyzing stock structure and geographic variation and merits further comparison (Bembo et al., 1995, 1996a, 1996b; Magoulas et al., 1996; Tudela et al., 1999). Like E. japonicus, E. encrasicolus is a small pelagic fish that is distributed in the Mediterranean Sea, Black Sea, and the Atlantic coasts of North Africa and Europe. In the Mediterranean area, considerable genetic structuring in E. encrasicolus has been disclosed due to hydrographic and geologic barriers to migration, particularly in the eastern Mediterranean basin (Bembo et al., 1995, 1996a, 1996b; Magoulas et al., 1996). In any case, severely restricted gene flow between subpopulations has not been implicated by the data, even though different stocks in the Adriatic Sea have been identified (Bembo et al., 1996a). However, a study on anchovies from 3 distinct spawning grounds in the northwest Mediterranean pointed to a panmictic structure, probably under the influences of strong gene flow (Tudela et al., 1999). It appears that, like geographic barriers, hydrologic features in the general areas encompassing spawning grounds would play a key role in shaping population structure. This is likely to be the case for E. japonicus.

Finally, in measures to protect the Japanese anchovy, the eastern and western spawning populations should be considered as 2 separate units. Even for the fisheries of the 2 separate units, the harvest could well involve exploitation of mixed native stocks as the deviation from HardyWeinberg equilibrium of the combined samples may indicate. A series of adult specimens from their natural feeding grounds and from other spawning grounds (Iseki and Kiyomoto, 1997; Aoki and Miyashita, 2000; Nakata et al., 2000) is desired for future genetic analyses to offer a finer resolution to the population structure of the species, as in the European eel (Wirth and Bernatchez, 2001).

\section{ACKNOWLEDGMENTS}

Yu-Ying Liao offered technical support for molecular cloning. Hwei-Yu Chang read and commented on an earlier draft. Financial support was granted to T.S.C. and to H.T.Y. by the National Science Council of the Republic of China. We thank them all.

\section{REFERENCES}

Aoki, I., and Miyashita, K. (2000). Dispersal of larvae and juveniles of Japanese anchovy Engraulis japonicus in the Kuroshio extension and Kuroshio-Oyashio transition regions, western North Pacific Ocean. Fish Res 49:155-164.

Beacham, T.D., Pollard, S., and Le, K.D. (2000). Microsatellite DNA population structure and stock identification of steelhead trout (Oncorhynchus mykiss) in the Nass and Skeena Rivers in northern British Columbia. Mar Biotechnol 2:587-600.

Bembo, D.G., Carvalho, G.R., Snow, M., Cingolani, N., and Pitcher, T.J. (1995). Stock discrimination among European anchovies, Engraulis encrasicolus, by means of PCR-amplified mitochondrial DNA analysis. Fish Bull (US) 94:31-40.

Bembo, D.G., Carvalho, G.R., Cingolani, N., Arneri, E., Giannetti, G., and Pitcher, T.J. (1996a). Allozymic and morphometric evidence for two stocks of the European anchovies Engraulis encrasicolus in Adriatic waters. Mar Biol 126:529-538.

Bembo, D.G., Carvalho, G.R., Cingolani, N., and Pitcher, T.J. (1996b). Electrophoretic analysis of stock structure in Northern Mediterranean anchovies, Engraulis encrasicolus. ICES J Mar Sci 53:115-128.

Chiu, T.S., Young, S.S., and Chen, C.S. (1997). Monthly variation of larval anchovy fishery in I-Lan Bay, NE Taiwan, with an evaluation for optimal fishing season. J Fisher Soc Taiwan 24:273-282.

Chiu, T.S., Lee, Y.J., Huang, S.W., and Yu, H.T. (2002). Polymorphic microsatellite markers for stock identification in Japanese anchovy (Engraulis japonica). Mol Ecol Note 2:44-50.

Dallas, J.F., Dod, B., Boursot, P., Prager, E.M., and Bonhomme, F. (1995). Population subdivision and gene flow in Danish house mice. Mol Ecol 4:311-320.

Excoffier, L., Smouse, L.P.E., and Quattro, J.M. (1992). Analysis of molecular variance inferred from metric distances among DNA haplotypes: application to human mitochondrial DNA restriction data. Genetics 131:479-491.

Goudet, J. (1995). FSTAT (Version 1.2): a computer program to calculate F-statistics. J Hered 86:485-486. 


\section{Hon-Tsen Yu et al.}

Grant, W.S. (1985). Biochemical genetic stock structure of the southern African anchovy, Engraulis capensis Gilchrist. J Fish Biol $27: 23-29$.

Guo, S.W., and Thompson, E.A. (1992). Performing the exact test of Hardy-Weinberg proportion for multiple alleles. Biometrics 48:361-372.

Hartl, D.L., and Clark, A.G. (1989). Population subdivision and migration. In: Principles of Population Genetics. Sunderland, thass.: Sinauer Associates Press, 281-326.

Hedgecock, D., Hutchison, E.S., Li, G., Sly, F.L., and Nelson, K. (1989). Genetic and morphometric variation in the Pacific sardine, Sardinops sagax caerulea: comparisons and contrasts with historical data and with variability in the northern anchovy, Engraulis mordax. Fish Bull (US) 87:653-671.

Hirakawa, K., Goto, T., and Hirai, M. (1997). Diet composition and prey size of larval anchovy, Engraulis Japonicus, in Toyama Bay, southern Japan Sea. Bull Jpn Sea Natl Fishery Res Inst 47:67-78.

Iseki, K., and Kiyomoto, Y. (1997). Distribution and settling of Japanese anchovy (Engraulis japonicus) eggs at the spawning ground off Changjiang River in the East China Sea. Fish Ocean 6:205-210.

Jarne, P., and Lagoda, P.J.L. (1996). Microsatellites, from molecules to populations and back. TREE 11:424-429.

Kimura, M., and Crow, J.F. (1964). The number of alleles that can be maintained in a finite population. Genetics 49:725-738.

Krebs, C.J. (1989). Ecological Methodology. New York, N.Y.: Harper \& Row, Publishers.

Magoulas, A., Tsimenides, N., and Zouros, E. (1996). Mitochondrial DNA phylogeny and the reconstruction of the population history of a species: the case of the European anchovy (Engraulis encrasicolus). Mol Biol Evol 13:178-190.

McCunne, B., and Mefford, M.J. (1999). Multivariate Analysis of Ecological Data. Version 4.17. Gleneden Brach, Ore.: MjM Software.

Moran, P.A.P. (1975). Wandering distributions and the electrophoretic profile. Theor Popul Biol 8:318-330.

Nakata, H., Kimura, S., Okazaki, Y., and Kasai, A. (2000). Implications of meso-scale eddies caused by frontal disturbances of the Kuroshio current for anchovy recruitment. J Mar Sci 57:143152.

Nei, M. (1978). Estimation of average heterozygosity and genetic distance from a small number of individuals. Genetics 89:583-590.

Ohta, T., and Kimura, M. (1973). A model of mutation appropriate to estimate the number of electrophoretically detectable alleles in a finite population. Genet Res 22:201-204.
Olsen, J.B., Bentzen, P., Banks, M.A., Shaklee, J.B., and Young, S. (2000). Microsatellites reveal population identity of individual pink salmon to allow supportive breeding of a population at risk of extinction. Trans Am Fish Soc 129:232-242.

O'Reilly, P., and Wright, J.M. (1995). The evolving technology of DNA fingerprinting and its application to fisheries and aquaculture. J Fish Biol 47:29-55.

Pemberton, J.M., Slate, J., Bancroft, D.R., and Barrett, J.A. (1995). Nonamplifying alleles at microsatellite loci: a caution for parentage and population studies. Mol Ecol 4:249-252.

Pielou, E.C. (1984). The Interpretation of Ecological Data-A Primer on Classification and Ordination. New York, N.Y.: Wiley.

Plounevez, S., and Champalbert, G. (1999). Feeding behaviour and trophic environment of Engraulis encrasicolus (L.) in the Bay of Biscay. Est Coast Shelf Sci 49:177-191.

Raymond, M., and Rousset, F. (1995). GENEPOP (Version 1.2): population genetics software for exact tests and ecumenicism. $J$ Hered 86:248-249.

Roques, S., Duchesne, P., and Bernatchez, L. (1999). Potential of microsatellites for individual assignment: the north Atlantic redfish (genus Sebastes) species complex as a case study. Mol Ecol 8:1703-1717.

Sambrook, J., Fritsch, E.F., and Maniatis, T. (1989). Molecular Cloning: A Laboratory Manual, 2nd ed. Cold Spring Harbor, N.Y.: Cold Spring Harbor Laboratory Press.

Schneider, S., Roessli, D., and Excoffier, L. (2000). Arlequin Version 2.0: a Software for Population Genetics Data Analysis. Genetics and Biometry Laboratory, University of Geneva, Switzerland.

Sekino, M., Takagi, N., Hara, M., and Takahashi, H. (2001). Analysis of microsatellite DNA polymorphisms in rockfish Sebastes thompsoni and application to population genetics studies. Mar Biotechnol 3:45-52.

Shen, S.C. (1969). Comparative study of the gill structure and feeding habits of the anchovy, Engraulis japonica (Hout). Bull Inst Zool Acad Sinica 8:21-35.

Slatkin, M. (1995). A measure of population subdivision based on microsatellite allele frequencies. Genetics 139:457-462.

Tudela, S., Garcia-Marin, J.L., and Pla, C. (1999). Genetic structure of the European anchovy, Engraulis encrasicolus, 1: in the north-west Mediterranean. J Exp Mar Biol Ecol 234:95-109.

Ward, R.D., Woodmark, M., and Skibinski, D.O.F. (1994). A comparison of genetic diversity levels in marine, freshwater, and anadromous fishes. J Fish Biol 44:213-232.

Weber, J.L. (1990). Informativeness of human $(\mathrm{dC}-\mathrm{dA})_{\mathrm{n}} \cdot(\mathrm{dG}-$ $\mathrm{dT})_{\mathrm{n}}$ polymorphism. Genomics 7:524-530. 
Weir, B.S., and Cockerham C.C. (1984). Estimating F-statistics for the analysis of population structure. Evolution 38:13581370 .

Wirth, T., and Bernatchez, L. (2001). Genetic evidence against panmixia in the European eel. Nature 409:1037-1040.
Wright, J.M., and Bentzen, P. (1994). Microsatellites: genetic markers for the future. Rev Fish Biol Fish 4:384-388.

Young, S.S., and Chiu, T.S. (1994). Maturation of Japanese anchovy, Engraulis japonica T \& S., from I-lan Bay, NE Taiwan. Zool Stud 33:302-309. 